\title{
Seagrass consumption by native and a tropically associated fish species: potential impacts of the tropicalization of the northern Gulf of Mexico
}

\author{
K. L. Heck Jr. ${ }^{1,2, *}$, F. J. Fodrie ${ }^{3}$, S. Madsen ${ }^{4}$, C. J. Baillie ${ }^{5}$, D. A. Byron ${ }^{1}$ \\ ${ }^{1}$ Dauphin Island Sea Lab, Dauphin Island, AL 36528, USA \\ ${ }^{2}$ University of South Alabama, Mobile, AL 36688, USA \\ ${ }^{3}$ Institute of Marine Sciences, University of North Carolina at Chapel Hill, Morehead City, NC 28557, USA \\ ${ }^{4}$ Atlantic States Marine Fisheries Commission, Arlington, VA 22201, USA \\ ${ }^{5}$ Marine Science Center, Northeastern University, Nahant, MA 01908, USA
}

\begin{abstract}
Temperatures are rising in most temperate and polar environments, and a welldocumented effect of this change is a poleward range shift by a wide variety of terrestrial and aquatic species. In the northern Gulf of Mexico (GOM), an increasing number of tropical species have recently become established among the extant warm-temperate fauna. These include a diversity of tropical fishes, manatees, green turtles, warm-water corals, and black mangroves. The impact of these species may be profound, primarily because temperate species are restricted from shifting northward by the North American land mass. Thus, as tropical species expand northward in the GOM, they must interact with the extant species and potentially compete for essential resources or become prey for each other. Here we focus on tropical immigrants capable of transforming the vast and highly productive seagrass systems of the northern GOM, emphasizing herbivorous parrotfishes and comparing their impact with endemic seagrass-resident fishes. Increased numbers of these herbivores (plus green turtles and manatees) would likely shift detritus-based food webs in seagrass meadows to webs dominated by direct consumption of seagrasses. We provide estimates of some expected consumption rates and effects of these tropically associated seagrass herbivores and predict that the consequences of the increased tropicalization of northern GOM seagrass meadows will be: substantially reduced standing crops and structural complexity of seagrass meadows; increased energy flux through grazing food webs; and a greatly reduced nursery role that will result in much smaller adult populations of those finfish and shellfish species that rely on seagrasses as nurseries.
\end{abstract}

KEY WORDS: Nicholsina usta - Lagodon rhomboides - Stephanolepis hispidus - Range shift · Climate change $\cdot$ Thalassia testudinum $\cdot$ Halodule wrightii $\cdot$ Herbivory

\section{INTRODUCTION}

Temperatures are rising in most of the world's temperate and polar environments, both on land and in the sea (Pachauri \& Reisinger 2007), and one welldocumented effect of these temperature increases are poleward range shifts by a wide variety of terrestrial and aquatic species. Range shifts result in the mixing of formerly isolated higher- and lower-latitude bio- tas. In the marine environment, historical data on fishery species in the North Sea have allowed reconstructions of range shifts and the faunal mixing that has occurred over the last half century (Perry et al. 2005). Similarly, tropical species from the Atlantic Ocean are moving into the western Mediterranean through the straits of Gibraltar while even greater numbers of species are moving northward from the Red Sea into the eastern Mediterranean via the Suez 
Canal (Ben Rais Lasram \& Mouillot 2009). The Gulf of Mexico (GOM) is no exception to this pattern, and the northern GOM has seen an increasing number of tropical species become established among its native warm-temperate fauna. For example, manatees Trichechus manatorum and green turtles Chelonia mydas are now much more frequently observed along the northern GOM coast than in the past (Fertl et al. 2005, Pabody et al. 2009, Avens et al. 2012), warm-water coral species not seen previously in the northern GOM, such as Acropora palmata, have established themselves (Precht \& Aronson 2006), formerly rare black mangroves Avicennia germinans have become established in several different locations (Comeaux et al. 2012), and a variety of tropical fishes have become common in the northern GOM at all stages of their life cycles (Fodrie et al. 2010, Fodrie \& Heck 2011). The impact of these tropical species on northern GOM ecosystems is mostly uninvestigated (but see Gericke et al. 2014), although it could be profound, primarily because temperate species are restricted from expanding their ranges northward by the adjacent North American land mass. Thus, as tropical species expand northward in the GOM, the extant species and the tropical immigrants are forced to interact, where they could compete for essential resources such as food and shelter, or become prey for one another.

In addition, recent reports have shown that large changes can take place in food-web structure or habitat availability when tropical species increase in abundance. For example, a large increase in the abundance of herbivorous green turtles in a marine reserve in the Indian Ocean resulted in a decline in seagrass biomass and a shift from large to small growth-form species, changes driven by the intense feeding activities of the turtles on the previously most abundant species of seagrass (Lal et al. 2010). This shift in the structure of seagrass meadows led to a loss of fishery production because the reduced stature of the seagrass remaining after turtle gazing did not afford juvenile fishes effective shelter from predators. Thus, the adult populations and harvests of valuable fishery species ultimately declined (Lal et al. 2010). In another study in the Lakshadweep Islands in the Indian Ocean, Kelkar et al. (2013) investigated the effects of increased green turtle densities in several marine protected areas. They measured localized herbivory rates that varied from near 0 to $>100 \%$ of the total primary production of seagrasses. Large losses of seagrass biomass would ultimately translate to loss in fisheries production as the nursery function provided by the above-ground biomass to young of the year and juvenile fishes would be lost, as seen by Lal et al. (2010).

Similarly, a study by Fourqurean et al. (2010) on green turtle impacts in Bermudean seagrass meadows concluded that recent increases in green turtle populations also likely led to dramatic reductions in turtlegrass. The use of exclusion cages allowed Fourqurean et al. (2010) to show that green turtle grazing reduced shoot density by about $20 \%$, and that aboveground biomass was nearly 3 times greater in caged than uncaged areas. In the northern GOM, poleward-shifting tropical species capable of producing similar top-down effects on the extensive and highly productive seagrass systems (Zieman \& Zieman 1989, Green \& Short 2003) include the same green turtle species studied by Lal et al. (2010), Fourqurean et al. (2010), and Kelkar et al. (2013), manatees, and several species of herbivorous parrotfish. At present, however, herbivory of seagrasses by turtles, manatees, and parrotfish in most of the northern GOM is presumed to be less important than that of native sea urchins (primarily the purple urchin Lytechinus variegatus; Heck \& Valentine 1995, 2006), whose grazing can locally denude seagrass meadows during population outbreaks (Rose et al. 1999; see review by Valentine \& Duffy 2006).

The recent influx of emerald parrotfish Nicholsina usta and several other tropical parrotfish species recorded by Fodrie et al. (2010) could produce large impacts on the structure and function of northern GOM seagrass meadows if their local densities approached levels of Caribbean seagrassresident herbivores like the bucktooth parrotfish Sparisoma radians (Lobel \& Ogden 1981). Here we provide experimental estimates of the consumption rates of the increasingly abundant emerald parrotfish, and compare them with those of 2 common indigenous seagrass consumers (pinfish Lagodon rhomboides and planehead filefish Stephanolepis hispidus) of the northern GOM. We also provide information on the stomach contents of these 3 species, as well as species-specific gut passage rates. We use these data to estimate how parrotfish densities approaching those seen in tropical locations could, in combination with native seagrass consumers, produce shifts in energy flux, habitat structure, and the secondary production of finfish and shellfish in northern GOM seagrass meadows. We conclude with a brief consideration of the large effects that grazers likely had on paleo-seagrass meadows, and a prediction that we may see a return to similar conditions if warming in the northern GOM continues. 


\section{MATERIALS AND METHODS}

\section{Herbivore species}

Of the 2 common native seagrass consumers, pinfish are by far the most abundant. For example, pinfish comprised about $60 \%$ of the total demersal fish collected during a $5 \mathrm{yr}$ study of northern GOM seagrass meadows (Fodrie \& Heck 2011). Pinfish experience ontogenetic changes in gut morphology and dentition (Stoner \& Livingston 1984) that reflects their shift from mostly carnivory to herbivory at sizes greater than $100 \mathrm{~mm}$ standard length (SL). At these larger sizes, pinfish consume mostly algae and seagrasses (Stoner 1980).

Planehead filefish comprise only about $2 \%$ of the demersal fishes collected by trawl in northern GOM seagrass meadows (Fodrie \& Heck 2011), where they feed mostly on seagrass-associated animals, and to a lesser extent, on seagrasses themselves (Clements \& Livingston 1983). Much like pinfish, larger filefish feed more heavily on seagrass than smaller individuals, and turtlegrass comprised nearly $40 \%$ of the stomach contents of filefish in the 71-89 $\mathrm{mm}$ SL size class (Clements \& Livingston 1983).

Less is known about the biology of the emerald parrotfish in the GOM. Abundances of this species have increased nearly 25 -fold in trawl catches since the 1970s, and currently this species ranks among the top 20 most abundant fishes in trawl surveys (cf. Livingston 1985 vs. Fodrie et al. 2010). Emerald parrotfish are known to inhabit turtlegrass-dominated meadows throughout their life (Peña et al. 2004), and stomach-content data from the northern GOM show them to be entirely herbivorous, with seagrass comprising 80 to $100 \%$ of the material in their guts (Prado \& Heck 2011).

\section{Collection and maintenance of herbivores}

Fishes used for gut-content analysis were collected from bays in northwest Florida, USA, including Big Lagoon (Perdido Bay system), Pensacola Bay, Choctawhatchee Bay, St. Andrew's Bay, and St. Joseph Bay, in the summer and fall of 2010 and 2011 (Fig. 1). Fish used in gut-clearance experiments were collected from St. Andrew's Bay and St. Joseph Bay in summer and fall of 2011. All fish were collected using a $5 \mathrm{~m}$ otter trawl $(2 \mathrm{~cm}$ body mesh; $0.6 \mathrm{~cm}$ bag mesh; $0.3 \mathrm{~m} \times 0.7 \mathrm{~m}$ doors), and fish used in gutcontent analysis were stored in plastic bags and kept in coolers until they were frozen for later processing.

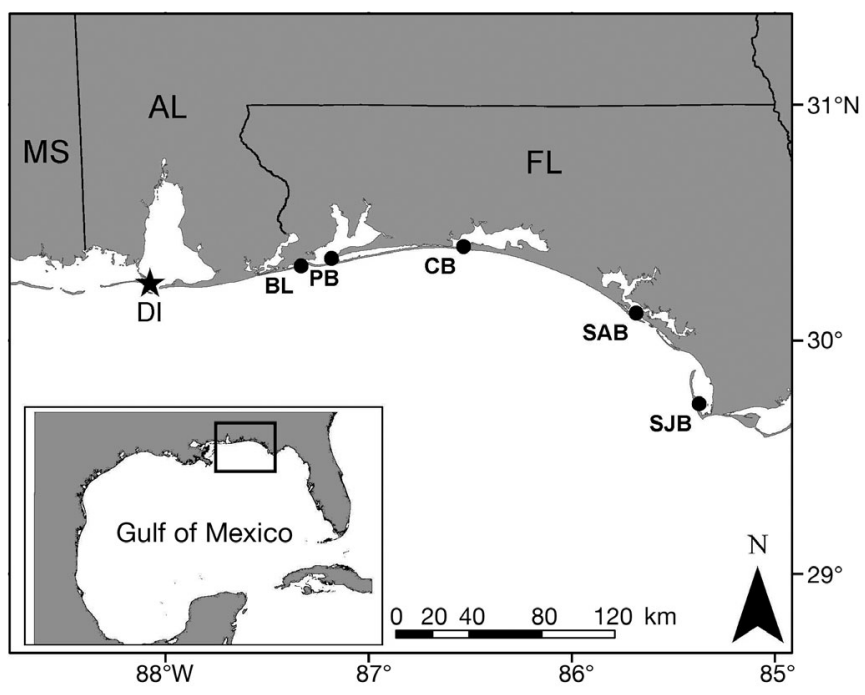

Fig. 1. Study area and sampling locations in the northern Gulf of Mexico (DI: Dauphin Island Sea Lab, where fish were transported for laboratory feeding trials, BL: Big Lagoon, PB: Perdido Bay, CB: Choctawhatchee Bay, SAB: St. Andrew's Bay, SJB: St. Joseph Bay)

Fish used in gut-clearance experiments were held in flow-through aquaria at the Dauphin Island Sea Lab, Alabama, and fed a combination of Ocean Nutrition Formula Two pellets, turtlegrass Thalassia testudinum (parrotfish and filefish), and shoalgrass Halodule wrightii (pinfish) prior to use in experiments.

\section{Gut-content analyses}

We examined the gut contents of 152 pinfish, 142 planehead filefish, and 48 emerald parrotfish. Individuals of each species were weighed (g) and measured $(\mathrm{mm})$ before gut contents were removed. The digestive tract was dissected by making cuts at the base of the esophagus and the intestines and the contents were removed from the stomach and intestines. Once the contents were separated to the lowest identifiable level, wet weights were determined and recorded. Seagrass wet weight was converted to dry weight (DW) using a $10 \%$ conversion factor (Short \& Coles 2001). Weights of gut contents were compared among species using a Kruskal-Wallis test, and pairwise comparisons were completed using Dunn's method $(\mathrm{p}<0.05)$.

\section{Gut-clearance experiments}

Fish were starved at least $24 \mathrm{~h}$ prior to each experiment to ensure that alimentary tracts were cleared. 
Prior to each trial, individual fish were placed into aerated 10 gallon ( 37.9 l) aquaria and allowed to acclimate for $1 \mathrm{~h}$. Each trial included a single fish in an aquarium that was offered 3 shoots of seagrass with 3 leaves each and allowed to feed for $4 \mathrm{~h}$. The mean $\pm \mathrm{SD}$ total length (TL) of individuals used in the gut clearance experiments was $139.9 \pm 26.2 \mathrm{~mm}$ for emerald parrotfish, $76.6 \pm 19.1 \mathrm{~mm}$ for planehead filefish, and $163.1 \pm 12.0 \mathrm{~mm}$ for pinfish. We used 25 individuals of each fish species in these experiments.

Both emerald parrotfish and planehead filefish were offered $T$. testudinum, the most common species of seagrass in the Florida bays where they were collected, while pinfish were offered $H$. wrightii (based on our prior experience that pinfish do not readily consume $T$. testudinum in containment, and experimental evidence that pinfish prefer $H$. wrightii over $T$. testudinum; Prado \& Heck 2011). All T. testudinum leaves were scraped free of epiphytes before being used in feeding trials, while the narrow, lightly epiphytized leaves of $H$. wrightii were left unscraped.

Before and after feeding, seagrass shoots were disassembled and each leaf was photographed. Total seagrass leaf areas in the images were determined using SigmaScan Pro 5 software, and the changes in area after feeding were used to estimate consumption rates. The areas derived from SigmaScan calculations were later converted into DWs using a predetermined weight/area regression of: Weight = $[0.0381+(0.00604 \times \sqrt{ } \text { Area })]^{2}$. Seagrass consumption data were $\log _{10}$ transformed to correct for nonnormality, while variances were homogeneous. Results were compared using a 1-way analysis of variance and Tukey's pairwise multiple comparisons test $(\mathrm{p}<$ 0.05).

\section{Evacuation rate estimates}

At the end of $4 \mathrm{~h}$ feeding trials, all remaining seagrass was removed and fecal material siphoned out. Each hour for $6 \mathrm{~h}$ after feeding ceased and once at $20 \mathrm{~h}$ after feeding ceased, fecal material was collected and siphoned feces were dried at $60^{\circ} \mathrm{C}$. Total amounts of dried fecal material recovered after the $4 \mathrm{~h}$ feeding period were also weighed and summed. Weights were then converted into percentages of food remaining in the alimentary tract of each individual. Alimentary tract evacuation rates were calculated for each fish following the regression equation developed by Targett \& Targett (1990):

$$
\ln \left(W_{t}\right)=\ln \left(W_{0}\right)-\left(b_{t}\right)
$$

where $W_{t}$ is the percentage of food left in each individual's gut at time $t$ after feeding ceased, plus 1 to account for values of $0 ; W_{0}$ is the $y$-intercept, $t$ is time after feeding ceased, and the slope $b$ is the instantaneous gut evacuation rate. This exponential model assumes that the time necessary for full gut evacuation does not depend on the amount of food each fish was offered (but see Jobling 1981). Instantaneous gut evacuation rates were calculated for each individual and compared among species using a Kruskal-Wallis test and Tukey's pairwise multiple comparisons test.

\section{Daily consumption rate estimates}

To further describe the impact that herbivorous fishes could have on northern GOM seagrasses, we calculated estimates of the daily per capita consumption rates of parrotfish, pinfish, and filefish. This was done using 2 complementary yet independent approaches to constrain potential study biases, with both approaches based on an assumed $12 \mathrm{~h}$ feeding day for these highly visual species. First, we used the $4 \mathrm{~h}$ feeding trials to estimate daily per capita consumption by multiplying the upper and lower confidence intervals of our consumption rates by 3 (i.e. $3 \times 4 \mathrm{~h}$ trials $=\mathrm{a} 12 \mathrm{~h}$ feeding day). Second, we used the gut clearance rate data from mesocosm trials to scale gut content data of fishes relative to seagrass biomass consumed per $12 \mathrm{~h}$ day (i.e. if gut clearance rates were estimated at $6 \mathrm{~h}$ for complete evacuation, we doubled the seagrass biomass found in fish stomachs to estimate daily consumption). We did not conduct any further statistical analyses on these derived estimates given that gut contents, as well as feeding trial consumption and evacuation rates, had already been analyzed separately for statistical significance.

\section{RESULTS}

\section{Gut content analysis}

We found a significant difference among fish species in the amount of seagrass biomass in their digestive tracts (Fig. 2; $F=178.16, \mathrm{p}<0.001$ ). Parrotfish and pinfish guts contained nearly 10 times the average weight of seagrass that occurred in filefish stomachs, and this difference was highly significant. Although parrotfish and pinfish did not differ significantly (Fig. 2), parrotfish often contained more seagrass biomass per unit length than pinfish or filefish (Fig. 3). Parrotfish stomachs contained only Thalassia 


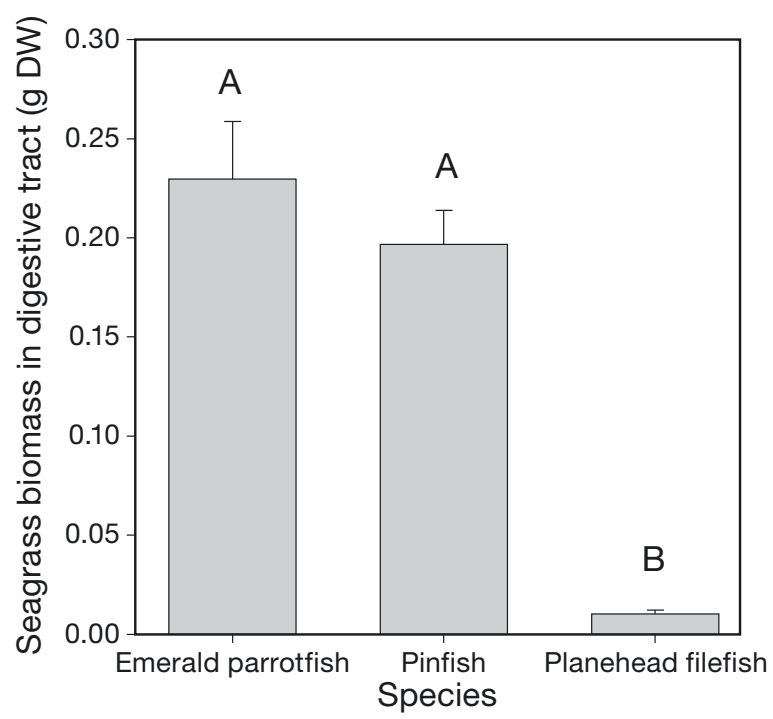

Fig. 2. Average seagrass biomass (in g dry weight, DW) from gut content analyses (+ $1 \mathrm{SE})$. Different letters above bars denote significant differences $(p<0.05)$ between species. Number of each species analyzed was: 48 emerald parrotfish Nicholsina usta, 152 pinfish Lagodon rhomboides, and 142 filefish Stephanolepis hispidus

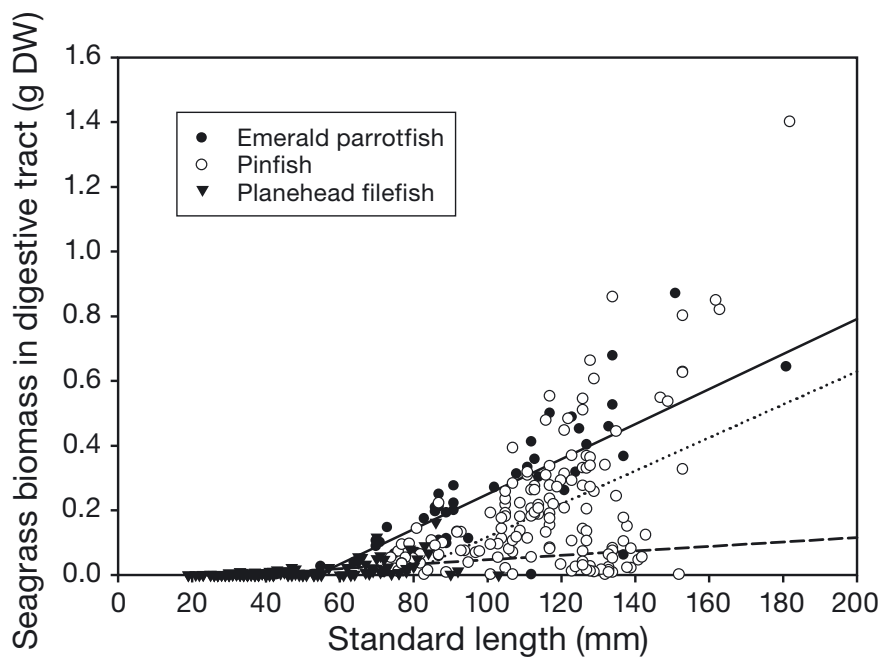

Fig. 3. Seagrass biomass found in the digestive tract of each of the 3 fish species by size. Lines represent linear regressions as follows: Seagrass biomass $=-0.291+(0.00541 \times$ Parrotfish length), $F=95.078, \mathrm{r}^{2}=0.674, \mathrm{p}<0.001$ (solid line); Seagrass biomass $=-0.394+(0.00511 \times$ Pinfish length $), F=52.112, \mathrm{r}^{2}=$ $0.258, \mathrm{p}<0.001$ (dotted line); and Seagrass biomass $=-0.0214$ $+(0.000685 \times$ Filefish length $), F=60.789, \mathrm{r}^{2}=0.303, \mathrm{p}<0.001$ (dashed line). Number of each species analyzed was: 48 emerald parrotfish Nicholsina usta, 152 pinfish Lagodon rhomboides, and 142 filefish. DW: dry weight

while pinfish contained a Halodule and Thalassia mixture. However, the advanced state of digestion prevented us from determining the exact amount of each seagrass species in pinfish stomachs.

\section{Consumption rates and gut-clearance experiments}

Results from the feeding and gut-clearance experiments revealed that non-native parrotfish consumed significantly more seagrass than native pinfish and filefish $\left(F_{2,12}=62.97, \mathrm{p}<0.001\right.$; Fig. 4). Parrotfish consumed an average of about $0.095 \mathrm{~g} \mathrm{DW}$, or $38 \%$ of the total grass offered, while pinfish consumed an average of approximately $0.015 \mathrm{~g} \mathrm{DW}$ or $16 \%$, and the average filefish consumption was only about $0.024 \mathrm{~g}$ DW or nearly $5 \%$. There was also a significant effect of species on the instantaneous gut evacuation rates (Kruskal-Wallis $H_{2}=23.667$, p < 0.001; Fig. 5), with non-native parrotfish clearing their alimentary tracts significantly faster than both native pinfish and filefish (Fig. 5). Parrotfish mean instantaneous evacuation rate was 20 to $80 \%$ faster than that of pinfish and approximately 100 to $600 \%$ faster than filefish evacuation rates (Table 1).

\section{Daily consumption rate estimates}

Parrotfish consumed 0.22 to $0.33 \mathrm{~g}$ DW seagrass fish $^{-1} \mathrm{~d}^{-1}$ based on feeding trials and approximately 0.24 to $0.35 \mathrm{~g}$ DW seagrass fish ${ }^{-1} \mathrm{~d}^{-1}$ based on gut contents and clearance rates. Pinfish consumed much less seagrass each day, although the grazing rate we determined for this species was more sensitive to the source of the estimate: 0.04 to $0.05 \mathrm{~g} \mathrm{DW}$

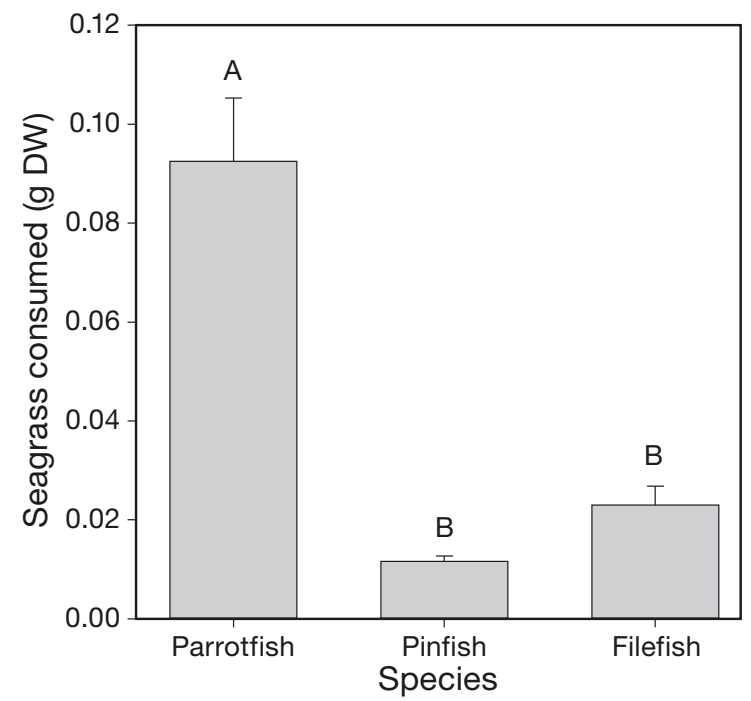

Fig. 4. Average seagrass consumption (in g dry weight, DW) from $4 \mathrm{~h}$ of feeding during gut clearance experiments by species (+1 SE). Different upper case letters denote significant differences $(\mathrm{p}<0.05)$ between species; $\mathrm{n}=25$ for each species (emerald parrotfish Nicholsina usta, pinfish Lagodon rhomboides, and filefish Stephanolepis hispidus) 


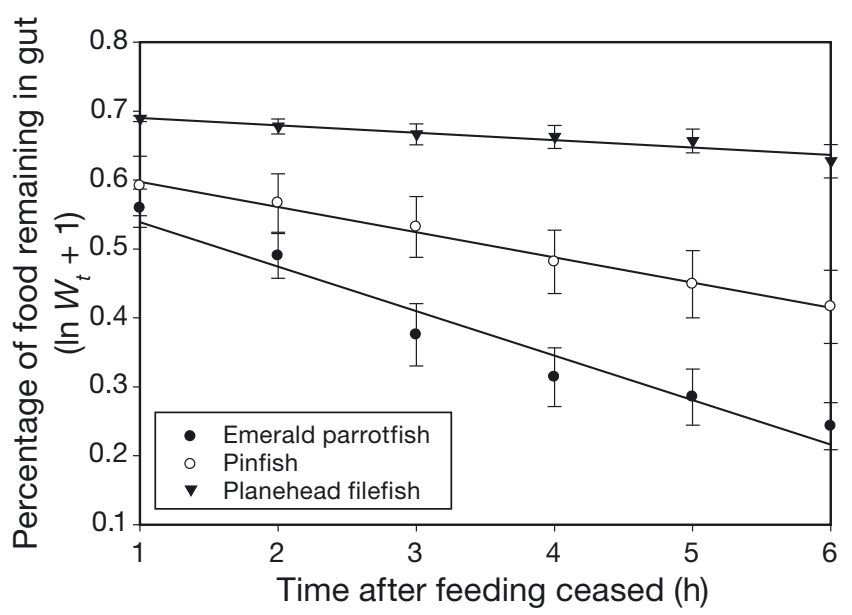

Fig. 5. Linear relationships between the percentage of food remaining in digestive tract and the time after feeding ceased for each of the 3 species; $\mathrm{n}=25$ for each species (emerald parrotfish Nicholsina usta, pinfish Lagodon rhomboides, and filefish Stephanolepis hispidus). $W_{t}$ is the percentage of food left in each individual's gut at time $t$ after feeding ceased, plus 1 to account for values of 0

fish $^{-1} \mathrm{~d}^{-1}$ based on feeding trials and 0.11 to $0.24 \mathrm{~g}$ DW fish ${ }^{-1} \mathrm{~d}^{-1}$ derived from gut contents and clearance rates. Comparatively, filefish account for relatively little grazing on a per capita basis: 0.05 to $0.09 \mathrm{~g} \mathrm{DW}$ fish $^{-1} \mathrm{~d}^{-1}$ based on feeding trials and $\leq 0.01 \mathrm{~g} \mathrm{DW}_{\text {fish }}{ }^{-1} \mathrm{~d}^{-1}$ derived by combining gut content and clearance rate information.

\section{DISCUSSION}

The effect of per capita herbivory on seagrass by native planehead filefish and pinfish was much less than that of the emerald parrotfish. For example, the consumption and gut-passage times of the filefish clearly showed that their role as consumers of seagrass biomass is limited. Even though pinfish stomachs contained biomasses of seagrass that were not significantly different than those of emerald parrotfish (Fig. 2), their lower consumption rates (Fig. 4) and longer evacuation times (Table 1) indicated a comparatively lower impact on a per fish basis.
The turtlegrass consumption rates and gut-evacuation times of the bucktooth parrotfish previously studied by Randall (1968), Weinstein \& Heck (1979), and Lobel \& Ogden (1981), and those of the emerald parrotfish measured here, are substantially different. For comparison, Targett \& Targett (1990) calculated the average feeding rate of starved Sparisoma radians to be $0.383 \mathrm{~g} \mathrm{DW}$ over $4 \mathrm{~h}$, while we estimated average turtlegrass consumption rate of starved Nicholsina usta to be approximately $0.095 \mathrm{~g}$ DW over $4 \mathrm{~h}$ (Fig. 4), a rate less than $25 \%$ that of the bucktooth parrotfish. However, the reduced time for complete gut clearance by the emerald parrotfish, compared to that of the bucktooth reported by Targett \& Targett (1990), 9.35 h vs. 22.4 h, suggests that the total impact of the 2 species is more similar than the difference in consumption rates suggests. For example, since both species are likely visual, diurnal feeders, as are all the better known species of Caribbean parrotfish (Wilson et al. 2003), we can assume for comparison purposes that both species feed an average of $12 \mathrm{~h}$ $\mathrm{d}^{-1}$. Given that the gut evacuation time of the bucktooth is around 2.4 times that of the emerald parrotfish, this means that the daily consumption of emerald parrotfish will actually be around 50\% that of bucktooths, instead of less than $25 \%$ of bucktooth consumption as calculated from consumption rates without taking into account the different rates of gut passage.

We can project the changes in northern GOM seagrass ecosystems that might take place if emerald parrotfish continue to increase in abundance. While there are no published estimates of emerald parrotfish densities known to us, if we assume for discussion purposes that emerald parrotfish abundances were to increase to 1.0 ind. $\mathrm{m}^{-2}$, a density similar to our estimate for the larger (>100 mm TL) herbivorous pinfish in our study area (see below) and on par with what we have estimated for seagrass-resident parrotfish densities in tropical latitudes, they could consume approximately 0.22 to $0.35 \mathrm{~g} \mathrm{DW} \mathrm{fish}^{-1} \mathrm{~d}^{-1}$ (determined from our estimates of daily consumption described above using either feeding trials or via the product of gut contents and evacuation times). The

Table 1. Mean instantaneous gut evacuation rates for 3 fish species $( \pm 1 \mathrm{SE}, \mathrm{n}=25$ for each). Different superscripts denote significant differences $(\mathrm{p}<0.05)$ between species

\begin{tabular}{|lcc|}
\hline Species & Instantaneous evacuation rate & Time for complete evacuation (h) \\
\hline Emerald parrotfish Nicholsina usta & $-0.064524 \pm 0.006663^{\mathrm{a}}$ & $11.70 \pm 1.357457$ \\
Pinfish Lagodon rhomboides & $-0.038415 \pm 0.009501^{\mathrm{b}}$ & $15.82 \pm 3.120$ \\
Planehead filefish Stephanolepis hispidus & $-0.010714 \pm 0.003988^{\mathrm{b}}$ & $20.72 \pm 2.733$ \\
\hline
\end{tabular}


estimated aboveground turtlegrass production rate in the northern GOM's Perdido Bay is approximately $1.4 \mathrm{~g} \mathrm{DW} \mathrm{m}^{-2} \mathrm{~d}^{-1}$ (Mateo et al. 2006). Thus, at a density of 1 ind. $\mathrm{m}^{-2}$, the projected parrotfish consumption would equal around 16 to $25 \%$ of the daily aboveground production. In contrast, the consumption by pinfish is much smaller, since we estimate that densities in the size range that is mostly herbivorous (>100 mm SL) are no more than perhaps $1 \mathrm{~m}^{-2}$. With consumption rates around $20 \%$ of parrotfish based on feeding trials, and gut evacuation times longer by 2 to $8 \mathrm{~h}$ (Table 1), this results in an estimated turtlegrass consumption rate by pinfish that is only $\sim 17 \%$ (feeding trials) to $55 \%$ (gut contents and evacuation rates) of that recorded for parrotfish (0.04-0.24 $\mathrm{g} \mathrm{DW} \mathrm{d}^{-1}$, or a range of from about 2 to $9 \%$ of daily aboveground seagrass production). As pinfish preferentially graze on Halodule wrightii, their consumption of Thalassia testudinum is likely closer to the lower end of our estimates (i.e. $<0.1 \mathrm{~g} \mathrm{DW}$ fish $^{-1} \mathrm{~d}^{-1}$ ). Pinfish densities of all sizes have been estimated to be approximately $5 \mathrm{~m}^{2}$ in October in our study area (Harter \& Heck 2006). We assume that around $20 \%$ of these fish would likely be of the size that consumes seagrass (>100 mm TL), which then gives an estimated density of herbivorous pinfish of $1 \mathrm{~m}^{-2}$. For filefish, consumption rates are even lower, since we estimate a high filefish density to be less than 0.1 ind. $\mathrm{m}^{-2}$ (based on filefish densities relative to pinfish densities; Fodrie et al. 2010). This means that filefish consumption would be $<0.009 \mathrm{~g} \mathrm{DW} \mathrm{m}^{-2}$, or $<0.006 \%$ of the total daily aboveground production. Summarized, these calculations suggest that emerald parrotfish would consume around 16 to $25 \%$, while pinfish and filefish combined would consume around 5 to $10 \%$ of daily production.

\section{Historical comparisons and the future of GOM seagrass meadows}

In the past, seagrass consumption by the formerly abundant manatees and green turtles must have been enormous (cf. Jackson 1997, Jackson et al. 2001). For example, adult manatees are estimated to consume 35 to $50 \mathrm{~kg}$ wet wt plant material ind.$^{-1} \mathrm{~d}^{-1}$ (Etheridge et al. 1985). Domning (2001) and VelezJuarbe et al. (2012) speculated about the impact that the formerly diverse and very large (but now mostly extinct) herbivorous sea cows (manatees, dugongs, and related taxa) might have had on their seagrass forage. Some of these extinct species possessed substantial tusks that would have been effective in dig- ging up entire seagrass shoots, including roots and rhizomes. As Velez-Juarbe et al. (2012) noted, it seems likely that a great deal of seagrass production formerly went into grazing and not into detritusbased food webs as presently occurs (Zieman \& Zieman 1989). Intense grazing by tusked dugongids is also thought to have prevented monocultures of large seagrass species from forming and to have maintained diverse meadows that also contained smaller seagrass species (Velez-Juarbe et al. 2012).

Also relevant is the experimental study of green turtle impacts on Bermudean seagrass meadows (Fourqurean et al. 2010), in which increases in green turtle populations likely led to dramatic reductions in turtlegrass, and the similar studies in the Indian Ocean by Lal et al. (2010) and Kelkar et al. (2013), who found that increased turtle abundances decreased total seagrass biomass and shifted species dominance from larger to smaller, more rapidly growing species. As Lal et al. (2010) noted, fishermen reported reduced catches of targeted species after turtle abundances increased, and this was ascribed to the reduction in seagrass biomass that decreased shelter and survival rates for young-of-the-year fishes and ultimately led to decreased numbers of adult fishes.

A reduction in seagrass biomass and shelter for juvenile fishes thus seems possible in the northern GOM as herbivores increase in number and diversity. Reduced seagrass biomass would be expected to decrease the nursery function of seagrass meadows and ultimately produce many fewer finfish and shellfish juveniles that survive to adult sizes. This follows directly from the well-known positive relationships between seagrass biomass and the diversity and abundance of associated fishes (cf. Wyda et al. 2002, and references in Mattila et al. 2008). Overall, it seems likely that if the abundance and size of seagrass herbivores such as parrotfishes, green turtles, and manatees increases, seagrass meadows that already can experience overgrazing by sea urchins (Camp et al. 1973, Valentine \& Heck 1991) will become much smaller in average canopy height and structural complexity and support fewer juvenile finfish and shellfish than at present. This 'mowed lawn' appearance is likely the way seagrass meadows looked during much of their history, and as recently as several hundred years ago when megaherbivores were still abundant in the GOM (Jackson et al. 2001).

An additional reason to anticipate that the impact of increasing numbers of seagrass herbivores would be especially large in the northern GOM is because of the relatively low local productivity of turtlegrass 
and manatee grass Syringodium filiforme, species that are near the northern extent of their ranges. At northern GOM latitudes of around $30^{\circ} \mathrm{N}$, these species receive less solar insolation than they do near their centers of distribution in the tropics (which will not increase as global climate warms). A similar situation exists in Bermuda, a high latitude $\left(32^{\circ} \mathrm{N}\right)$ outpost for turtlegrass and manatee grass that is warmed by the Gulf Stream. Experimental evidence from mesocosms suggests that globally increasing temperatures should strengthen herbivore-plant interactions and ultimately result in greater consumer control of primary production (O'Connor 2009). Consequently, despite anticipated increases in plant production with regional warming, total seagrass biomass along with the structural and nursery functions of seagrass meadows could be reduced, owing to even greater changes in consumer metabolism and grazing rates that outpace and offset altered primary production (O'Connor et al. 2009).

In conclusion, our results lead us to hypothesize that the ultimate consequences of the increased tropicalization of northern GOM seagrass meadows will include a substantially reduced standing crop of seagrass, increased energy flux through the grazing food web, a greatly reduced nursery role of seagrasses for finfish and shellfish, and substantially reduced adult populations of those species that rely on seagrasses as juvenile nursery habitats.

Acknowledgements. We thank Joe Myers for help in the field and laboratory, Carolyn Wood for her help in manuscript preparation, Matthew Kenworthy for preparation of Fig. 1, and NOAA MARFIN and Northern Gulf Institute programs, as well as the Dauphin Island Sea Lab and the University of North Carolina Institute of Marine Sciences for financial support.

\section{LITERATURE CITED}

Avens L, Goshe LR, Harms CA, Anderson ET and others (2012) Population characteristics, age structure, and growth dynamics of neritic juvenile green turtles in the northeastern Gulf of Mexico. Mar Ecol Prog Ser 458: 213-229

> Ben Rais Lasram F, Mouillot D (2009) Increasing southern invasion enhances congruence between endemic and exotic Mediterranean fish fauna. Biol Invasions 11: $697-711$

Camp DK, Cobb S, van Breeveld JF (1973) Overgrazing of seagrasses by a regular urchin, Lytechinus variegatus. Bioscience 23:37-38

Clements WH, Livingston RJ (1983) Overlap and pollutioninduced variability in the feeding habits of filefish (Pisces: Monacanthidae) from Apalachee Bay, Florida. Copeia 1983:331-338
Comeaux RS, Allison MA, Bianchi TS (2012) Mangrove expansion in the Gulf of Mexico with climate change: implications for wetland health and resistance to rising sea levels. Estuar Coast Shelf Sci 96:81-95

$>$ Domning DP (2001) Sirenians, seagrasses, and Cenozoic ecological change in the Caribbean. Palaeogeogr Palaeoclimatol Palaeoecol 166:27-50

Etheridge K, Rathbun GB, Powell JA, Kochman HI (1985) Consumption of aquatic plants by the West Indian Manatee. J Aquat Plant Manag 23:21-25

Fertl D, Schiro A, Regan G, Adimey N and others (2005) Manatee occurrence in the Northern Gulf of Mexico west of Florida. Gulf Caribb Res 17:69-94

Fodrie FJ, Heck KL Jr (2011) Response of coastal fishes to the Gulf of Mexico oil disaster. PLoS ONE 6:e21609

Fodrie FJ, Heck KL Jr, Powers SP, Graham WM, Robinson KL (2010) Climate related, decadal scale assemblage changes of seagrass associated fishes in the northern Gulf of Mexico. Glob Change Biol 16:48-59

Fourqurean JW, Manuel S, Coates KA, Kenworthy WJ, Smith SR (2010) Effects of excluding sea turtle herbivores from a seagrass bed: overgrazing may have led to loss of seagrass meadows in Bermuda. Mar Ecol Prog Ser 419:223-232

Gericke RL, Heck KL Jr, Fodrie FJ (2014) Interactions between northern-shifting tropical species and native species in the northern Gulf of Mexico. Estuar Coast 37: 952-961

Green EP, Short FT (eds) (2003) World atlas of seagrasses. University of California Press, Berkeley, CA

Harter SL, Heck KL Jr (2006) Growth rates of juvenile pinfish (Lagodon rhomboides): effects of habitat and predation risk. Estuar Coast 29:318-327

Heck KL Jr, Valentine JF (1995) Sea urchin herbivory: evidence for large-scale effects in subtropical seagrass meadows. J Exp Mar Biol Ecol 189:205-217

> Heck KL, Valentine JF (2006) Plant-herbivore interactions in seagrass meadows. J Exp Mar Biol Ecol 330:420-436

Jackson JBC (1997) Reefs since Columbus. Coral Reefs 16(Suppl):S23-S32

Jackson JBC, Kirby MX, Berger WH, Bjorndal KA and others (2001) Historical overfishing and recent collapse of coastal ecosystems. Science 293:629-637

Jobling M (1981) The influences of feeding on the metabolic rate of fishes: a short review. J Fish Biol 18:385-400

Kelkar N, Arthur R, Marba N, Alcoverro T (2013) Green turtle herbivory dominates the fate of seagrass primary production in the Lakshadweep islands (Indian Ocean). Mar Ecol Prog Ser 485:235-243

> Lal A, Arthur R, Marbà N, Lill AWT, Alcoverro T (2010) Implications of conserving an ecosystem modifier: Increasing green turtle (Chelonia mydas) densities substantially alters seagrass meadows. Biol Conserv 143: 2730-2738

Livingston RJ (1985) Organization of fishes in a coastal seagrass system: the response to stress. In: Yáñez-Arancibia A (ed) Fish community ecology in estuaries and coastal lagoons. Universidad Nacional Autonoma de Mexico, Ciudad Universitaria, Mexico City, p 317-332

> Lobel PS, Ogden JC (1981) Foraging by the herbivorous parrotfish Sparisoma radians. Mar Biol 64:173-183

Mateo MA, Cebrián J, Dunton K, Mutchler T (2006) Carbon flux in seagrass ecosystems. In: Larkum AWD, Orth RJ, Duarte CM (eds) Seagrasses: biology, ecology and conservation. Springer, New York, NY, p 159-192 
Mattila J, Heck KL Jr, Millstein E, Miller E, Gustafsson C, Williams S, Byron D (2008) Increased habitat structure does not always provide increased refuge from predation. Mar Ecol Prog Ser 361:15-20

O'Connor MI (2009) Warming strengthens an herbivoreplant interaction. Ecology 90:388-398

O'Connor MI, Piehler MF, Leech DM, Anton A, Bruno JF (2009) Warming and resource availability shift food web structure and metabolism. PLoS Biol 7:e1000178

Pachauri RK, Reisinger A (eds) (2007) Contribution of Working Groups I, II and III to the Fourth Assessment Report of the Intergovernmental Panel on Climate Change. IPCC, Geneva

Pabody CM, Carmichael RH, Rice L, Ross M (2009) A new sighting network adds to 20 years of historical data on fringe West Indian manatee (Trichechus manatus) populations in Alabama waters. Gulf Mex Sci 27:52-61

Peña AA, Jimenez M, Villafranca S (2004) Abundancia y riqueza especifica de la ictiofauna asociada con Thalassia testudinum en el Golfo de Cariaco, Venezuela. Rev Biol Trop 52:973-980

> Perry AL, Low PJ, Ellis JR, Reynolds JD (2005) Climate change and distribution shifts in marine fishes. Science 308:1912-1915

> Prado P, Heck KL Jr (2011) Seagrass selection by omnivorous and herbivorous consumers: determining factors. Mar Ecol Prog Ser 429:45-55

Precht WF, Aronson RB (2006) Death and resurrection of Caribbean coral reefs: a paleoecological perspective. In: Côté I, Reynolds J (eds) Coral reef conservation. Cambridge University Press, Cambridge, p 40-77

Randall JE (1968) Caribbean reef fishes. T. F. H. Publ., Neptune City, NJ

Rose CD, Sharp WC, Kenworthy WJ, Hunt JH and others (1999) Overgrazing of a large seagrass bed by the sea urchin Lytechinus variegatus in Outer Florida bay. Mar Ecol Prog Ser 190:211-222

Short FT, Coles RG (eds) (2001) Global seagrass research

Editorial responsibility: Ivan Nagelkerken, Adelaide, South Australia, Australia methods. Elsevier Science, Amsterdam

Stoner AW (1980) Feeding ecology of Lagodon rhomboides (Pisces: Sparidae): variation and functional responses. Fish Bull 78:337-352

Stoner AW, Livingston RJ (1984) Ontogenetic patterns in diet and feeding morphology in sympatric sparid fishes from seagrass meadows. Copeia 1984:174-187

Targett TE, Targett NM (1990) Energetics of food selection by the herbivorous parrotfish Sparisoma radians: roles of assimilation efficiency, gut evacuation rate, and algal secondary metabolites. Mar Ecol Prog Ser 66:13-21

Valentine JF, Duffy JE (2006) The central role of grazing in seagrass ecology. In: Larkum AWD, Orth RJ, Duarte CM (eds) Seagrasses: biology, ecology and conservation. Springer, New York, NY, p 463-501

Valentine JF, Heck KL Jr (1991) The role of sea urchin grazing in regulating subtropical seagrass meadows: evidence from field manipulations in the northern Gulf of Mexico. J Exp Mar Biol Ecol 154:215-230

Velez-Juarbe J, Domning DP, Pyenson ND (2012) Iterative evolution of sympatric seacow (Dugongidae, Sirenia) assemblages during the past $\sim 26$ million years. PLoS ONE 7:e31294

Weinstein MP, Heck KL Jr (1979) Ichthyofauna of turtlegrass (Thalassia testudinum) meadows along the Caribbean coast of Panama and in the Gulf of Mexico: composition, structure and community ecology. Mar Biol 50:97-108

Wilson SK, Bellwood DR, Choat JH, Furnas MJ (2003) Detritus in the epilithic algal matrix and its use by coral reef fishes. Oceanogr Mar Biol Annu Rev 41:279-309

Wyda JC, Deegan LA, Hughes JE, Weaver MJ (2002) The response of fishes to submerged aquatic vegetation complexity in two ecoregions of the mid-Atlantic bight: Buzzards Bay and Chesapeake Bay. Estuaries 25:86-100

Zieman JC, Zieman RT (1989) The ecology of the seagrass meadows of the west coast of Florida: a community profile. Biol Rep 85. National Wetlands Research Center, USFWS, Slidell, LA

Submitted: February 2, 2014; Accepted: November 4, 2014 Proofs received from author(s): January 14, 2015 